\title{
EFIKASI HERBISIDA METIL METSULFURON TERHADAP GULMA PADA BUDIDAYA TANAMAN KARET (Hevea brasiliensis) BELUM MENGHASILKAN
}

\section{EFFICACY OF METSULFURON-METHYL HERBICIDE IN CONTROLLING WEEDS IN RUBBER PLANTATION (Hevea brasiliensis) IMMATURE PLANT}

\author{
Irvan Saputra ${ }^{1}$, Rusdi Evizal ${ }^{1}$, Dad Resiworo Jekti Sembodo ${ }^{2}$, dan Nanik Sriyani ${ }^{2}$ \\ 'Jurusan Agroteknologi, Fakultas Pertanian, Universitas Lampung, Bandar Lampung, Indonesia \\ ${ }^{2}$ Jurusan Agronomi, Fakultas Pertanian, Universitas Lampung, Bandar Lampung, Indonesia \\ *Email: irvansaputraagt14@gmail.com \\ * Corresponding Author, Diterima: 11 Feb. 2021, Direvisi: 20 Mei 2021, Disetujui: 20 Mei 2021
}

\begin{abstract}
This study aims to determine the rate of metsulfuron-methyl herbicide effectively controlling weeds in rubber plantations, determine changes in weed composition due to metsulfuron-methyl herbicide application, and determine whether phytotoxicity of rubber plants occurs after the application of metsulfuron-methyl herbicide. This research was conducted at farmers farm in Onoharjo Village,Terbanggi Besar Subdistrict, Central Lampung Regency and Weed Laboratory of the Faculty of Agriculture, University of Lampung during December 2017 to March 2018. This research used a randomized block design (RBD) with six treatments and four replications. The treatments are metsulfuron-methyl herbicide at $15 \mathrm{~g} / \mathrm{ha}, 20$ $\mathrm{g} / \mathrm{ha}, 25 \mathrm{~g} / \mathrm{ha}, 30 \mathrm{~g} / \mathrm{ha}$, mechanical weeding, and control plot. Homogenity of data was tested by the Bartlett test, data additivity was tested by the Tukey test, and differences in the mean value of the treatments were tested with the Least Significant Difference (LSD) test at 5\% level. The results showed that metsulfuronmethyl herbicide 15-30 g/ha was effective in controlling total weeds, broad leaf weeds, Borreria alata, and Praxelis climatidea at 4 - 12 weeks after application. Metsulfuron-methyl herbicide15-30 g/ha controled weed grass and sedges at 4 - 8 weeks after application. Metsulfuron-methylherbicide15-30 g/ha controls weed Axonopus compressus, Croton hirtus, and Ottochloanodosa at 4 weeks after application. Application of metsulfuron-methyl herbicide 15-30 g/ha resulted in change in composition of weeds at 4, 8 and 12 weeks after application. The application of metsulfuron-methyl herbicide $15-30 \mathrm{~g} / \mathrm{h}$ a didn't cause rubber phytotoxicity.
\end{abstract}

Keywords: Herbicide, methyl methulfuron, rubber, weeds.

\begin{abstract}
ABSTRAK
Penelitian ini bertujuan untuk mengetahui dosis herbisida metil metsulfuron yang efektif mengendalikan gulma di pertanaman karet, mengetahui perubahan komposisi gulma akibat aplikasi herbisida metil metsulfuron, dan mengetahui fitotoksisitas tanaman karet setelah aplikasi herbisida metil metsulfuron. Penelitian ini dilakukan di kebun rakyat Desa Onoharjo, Kecamatan Terbanggi Besar, Kabupaten Lampung Tengah dan Laboratorium Gulma Fakultas Pertanian Universitas Lampung dimulai Desember 2017 hingga Maret 2018. Penelitian ini menggunakan rancangan acak kelompok (RAK) dengan empat ulangan dan enam perlakuan yaitu dosis herbisida metil metsulfuron $15 \mathrm{~g} / \mathrm{ha}, 20 \mathrm{~g} / \mathrm{ha}, 25 \mathrm{~g} / \mathrm{ha}, 30 \mathrm{~g} / \mathrm{ha}$, penyiangan mekanis, dan kontrol. Homogenitas ragam data diuji dengan uji Bartlett, additivitas data diuji dengan uji Tukey, dan perbedaan nilai tengah perlakuan diuji dengan
\end{abstract}


uji Beda Nyata Terkecil (BNT) pada taraf 5\%. Hasil penelitian menunjukan herbisida metil metsulfuron dosis 15 $-30 \mathrm{~g} /$ ha efektif mengendalikan gulma total, gulma daun lebar, Borreria alata, dan Praxelis climatidea pada 4 - 12 MSA. Herbisida metil metsulfuron dosis $15-30 \mathrm{~g} /$ ha mengendalikan gulma rumput dan teki pada $4-8$ MSA. Herbisida metil metsulfuron dosis $15-30 \mathrm{~g} /$ ha mengendalikan gulma Axonopus compressus, Croton hirtus, dan Ottochloa nodosa pada 4 MSA di perkebunan karet TBM. Aplikasi herbisida metil metsulfuron dosis 15 - $30 \mathrm{~g} /$ ha menyebabkan terjadinya perubahan komposisi gulma Borreria alata menjadi Croton hirtus pada 4 MSA, Borreria alata menjadi Axonopus compressus pada 8 MSA, dan Borreria alata menjadi Ottochloa nodosa pada 12 MSA di perkebunan karet TBM. Aplikasi herbisida metil metsulfuron dosis 15 -30 g/ha tidak menyebabkan terjadinya keracunan terhadap tanaman karet TBM.

Kata kunci : Gulma, herbisida, karet, metil metsulfuron.

\section{PENDAHULUAN}

Indonesia merupakan negara agraris yang sebagian besar penduduknya memiliki mata pencaharian di sektor pertanian. Kegiatan pertanian yang dikembangkan dalam hal ini meliputi sektor perkebunan. Sektor perkebunan memegang peran penting dalam perekonomian Indonesia sebagai penghasil devisa negara. Data sementara yang diambil dari laporan Direktorat Jenderal Perkebunan 2018, luas lahan tanaman karet di Indonesia sebesar 3.606.245 ha pada 2014 meningkat menjadi 3.679.108 ha pada 2018 (Ditjenbun, 2018). Namun, produksi sektor perkebunan karet Indonesia belum maksimal salah satunya disebabkan oleh permasalahan gulma.

Gulma merupakan tumbuhan yang mengganggu atau merugikan kepentingan manusia sehingga manusia berusaha untuk mengendalikannya (Sembodo, 2010). Kerugian yang ditimbulkan berupa persaingan sarana tumbuh seperti air, unsur hara, cahaya matahari dan ruang tumbuh (Supawan dan Haryadi, 2014). Kerugian lainnya yaitu menurunkan efisiensi pemupukan dan menunda matang sadap tanaman karet (Evizal, 2015). Salah satu upaya yang dapat dilakukan untuk menekan kerugian tersebut yaitu dengan pengendalian gulma pada masa tanaman belum menghasilkan (TBM). Pengendalian gulma secara kimiawi menggunakan herbisida merupakan pengendalian yang umum digunakan pada tingkat perkebunan karena dinilai lebih efisien (Hastuti dkk., 2015). Herbisida metil metsulfuron merupakan herbisida pratumbuh dan pascatumbuh yang bersifat sistemik dan selektif mengendalikan gulma semusim dan tahunan dari golongan gulma berdaun lebar(Siregar, 2002). Aplikasi herbisida ini dikombinasi dengan herbisida ametrin efektif mengendalikan gulma total di perkebunan tebu (Susanto dkk., 2020). Aplikasi herbisida tepat dosis memiliki peran penting dalam tindakan pengendalian gulma secara kimiawi, dosis yang digunakan harus efektif mengendalikan gulma dan tidak menimbulkan keracunan pada tanaman budidaya.

Penelitian ini bertujuan untuk mengetahui dosis herbisida metilmetsulfuron efektifmengendalikan gulma di perkebunan karet belum menghasilkan, mengetahui perubahan komposisi gulmaakibat aplikasi herbisida metil metsulfuron, dan mengetahui apakah terjadi fitotoksisitas tanaman karet akibat aplikasi herbisida metil metsulfuron. 


\section{BAHAN DAN METODE}

Penelitian ini dilaksanakan di kebun rakyat Desa Onoharjo, Kecamatan Terbanggi Besar, Kabupaten Lampung Tengah dan Laboratorium Gulma Fakultas Pertanian Universitas Lampung dimulai Desember 2017 hingga Maret 2018. Bahan yang digunakan pada penelitian ini adalah gulma pada tanaman karet TBM berumur 4 tahun, kantong plastik, kantong kertas, air, dan herbisida metil metsulfuron 20\% (METAREX $20 \mathrm{WG).}$ Peralatan yang digunakan adalah knapsacksprayer, nozel biru, timbangan digital, oven, gelas ukur, meteran, cangkul, sabit dan kuadran besi ukuran 0,5m x 0,5m.

Penelitian ini menggunakan rancangan acak kelompok (RAK), terdapat 24 satuan percobaan dengan 6 taraf perlakuan dan 4 ulangan. Perlakuan tersebut terdiri dari perlakuan dosis herbisida metil metsulfuron $15 \mathrm{~g} / \mathrm{ha}, 20 \mathrm{~g} / \mathrm{ha}, 25 \mathrm{~g} / \mathrm{ha}, 30 \mathrm{~g} / \mathrm{ha}$, penyiangan mekanis, dan kontrol (tanpa pengendalian gulma). Homogenitas ragam data digunakan uji Bartlett dan additivitas data diuji dengan uji Tukey. Jika asumsi terpenuhi, maka data dianalisis dengan sidik ragam dan perbedaan nilai tengah perlakuan diuji dengan uji Beda Nyata Terkecil (BNT) pada taraf 5\%. Satuan petak terdiri atas gulma di bawah 4 tanaman karet dengan umur tanaman sekitar 4 tahun dengan luas $3 \mathrm{~m}$ x $11 \mathrm{~m}$ (luas $33 \mathrm{~m}^{2}$ ). Petak lahan yang digunakan kondisi penutupan gulmanya $>75 \%$. Volume semprot yang diperoleh yaitu 454 1/ha.

Pengambilan gulma dilakukan sebanyak 2 titik kuadran untuk setiap pengamatan pada petak perlakuan. Waktu pengambilan gulma untuk data biomassa dilakukan pada 4, 8, dan 12 minggu setelah aplikasi (MSA). Pengamatan bobot kering gulma dilakukan dengan memotong gulma tepat setinggi permukaan tanah pada petak seluas $0,5 \times 0,5 \mathrm{~m}$ kemudian gulma dipilah sesuai jenisnya. Gulma dikeringkan dengan cara dioven selama 48 jam dengan suhu $80^{\circ} \mathrm{C}$ hingga mencapai bobot konstan kemudian ditimbang. Pengambilan gulma dilakukan untuk menentukan dan menganalisis efikasi herbisida serta summed dominance ratio (SDR). Nilai SDR gulma (Summed Dominance Ratio) digunakan untuk menentukan urutan gulma dominan yang ada. Nilai C menunjukkan kesamaan komposisi gulma antara perlakuan yang dibandingkan. Jika nilai C lebih dari 75\% maka kedua komunitas yang dibandingkan memiliki tingkat kesamaan komposisi(Tjitrosoedirdjo dkk., 1984).

Pengamatan fitotoksisitas dilakukan secara visual dengan membandingkan antara tanaman karet pada petak perlakuan dosis herbisida metil metsulfuron dengan tanaman karet pada petak penyiangan mekanis. Jumlah tanaman karet yang diamati untuk pengamatan fitotoksisitas sebanyak 4 tanaman karet setiap petak perlakuan. Tingkat keracunan tanaman karet dinilai secara visual pada pengamatan 4, 8, dan 12 MSA.

\section{HASIL DAN PEMBAHASAN}

\section{Bobot Kering Gulma Total}

Hasil penelitian (Tabel 1) menunjukkan herbisida metil metsulfuron dosis $15-30 \mathrm{~g} / \mathrm{ha}$ dan penyiangan mekanis efektif mengendalikan gulma total pada 4, 8, dan 12 MSA (Minggu Setelah Aplikasi). Herbisida metil metsulfuron antardosis yang diuji tidak menunjukan perbedaan daya kendali terhadap pertumbuhan gulma total. Hal ini sejalan dengan hasil penelitian Koriyando dkk. (2014), perlakuan herbisida 
Tabel 1. Pengaruh perlakuan herbisida metil metsulfuron terhadap bobot kering gulma total

\begin{tabular}{lcccc}
\hline \multirow{2}{*}{ Perlakuan } & 4 MSA & 8 MSA & \multicolumn{2}{c}{$12 \mathrm{MSA}$} \\
\cline { 2 - 5 } & Data asli & Data asli & Data asli & $\sqrt{(\mathrm{x}+0,5)}$ \\
\hline & & $\ldots \ldots \ldots \ldots \ldots \ldots \ldots \ldots \ldots \ldots \ldots$ & \\
Metil metsulfuron $15 \mathrm{~g} / \mathrm{ha}$ & $3,24 \mathrm{~b}$ & $3,71 \mathrm{~b}$ & 12,17 & $3,50 \mathrm{bc}$ \\
Metil metsulfuron 20 g/ha & $5,94 \mathrm{~b}$ & $1,95 \mathrm{~b}$ & 16,7 & $4,04 \mathrm{~b}$ \\
Metil metsulfuron 25 g/ha & $2,32 \mathrm{~b}$ & $1,95 \mathrm{~b}$ & 6,89 & $2,66 \mathrm{c}$ \\
Metil metsulfuron 30 g/ha & $1,93 \mathrm{~b}$ & $1,78 \mathrm{~b}$ & 6,4 & $2,59 \mathrm{c}$ \\
Penyiangan mekanis & $1,21 \mathrm{~b}$ & $2,51 \mathrm{~b}$ & 9,62 & $3,10 \mathrm{bc}$ \\
Kontrol & $58,39 \mathrm{a}$ & $42,46 \mathrm{a}$ & 46,52 & $6,85 \mathrm{a}$ \\
\hline BNT 5\% & 4,73 & 2,72 & & 1,04 \\
\hline
\end{tabular}

Keterangan : Nilai tengah pada setiap kolom yang diikuti huruf yang sama tidak berbeda nyata menurut uji BNT pada taraf $5 \%$.

Tabel 2. Pengaruh perlakuan herbisida metil metsulfuron terhadap bobot kering gulma daun lebar

\begin{tabular}{|c|c|c|c|c|}
\hline \multirow[b]{2}{*}{ Perlakuan } & \multicolumn{2}{|c|}{$4 \mathrm{MSA}$} & \multirow{2}{*}{$\begin{array}{c}\text { 8 MSA } \\
\text { Data asli }\end{array}$} & \multirow{2}{*}{$\begin{array}{l}12 \mathrm{MSA} \\
\text { Data asli }\end{array}$} \\
\hline & Data asli & $\sqrt{ } \sqrt{ }(x+0,5)$ & & \\
\hline & \multicolumn{4}{|c|}{ 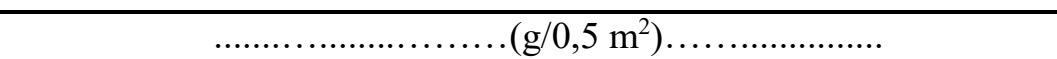 } \\
\hline Metil metsulfuron $15 \mathrm{~g} / \mathrm{ha}$ & 2,55 & $1,26 \mathrm{~b}$ & $0,92 \mathrm{~b}$ & $8,79 \mathrm{~b}$ \\
\hline Metil metsulfuron $20 \mathrm{~g} / \mathrm{ha}$ & 4,66 & $1,40 \mathrm{~b}$ & $0,51 \mathrm{~b}$ & $3,88 \mathrm{~cd}$ \\
\hline Metil metsulfuron $25 \mathrm{~g} / \mathrm{ha}$ & 1,87 & $1,06 \mathrm{~b}$ & $0,12 \mathrm{~b}$ & $3,09 \mathrm{~cd}$ \\
\hline Metil metsulfuron $30 \mathrm{~g} / \mathrm{ha}$ & 1,30 & $1,08 \mathrm{~b}$ & $0,37 \mathrm{~b}$ & $0,95 \mathrm{~d}$ \\
\hline Penyiangan mekanis & 1,05 & $1,04 \mathrm{~b}$ & $1,27 \mathrm{~b}$ & $6,20 \mathrm{bc}$ \\
\hline Kontrol & 52,19 & $2,69 \mathrm{a}$ & $36,20 \mathrm{a}$ & $43,97 \mathrm{a}$ \\
\hline BNT 5\% & & 0,43 & 2,11 & 3,83 \\
\hline
\end{tabular}

Keterangan : Nilai tengah pada setiap kolom yang diikuti huruf yang sama tidak berbeda nyata menurut uji BNT pada taraf $5 \%$.

metil metsulfuron pada dosis $15,75 \mathrm{~g} / \mathrm{ha}, 21 \mathrm{~g} / \mathrm{ha}, 26,25$

$\mathrm{g} /$ ha dan $31,5 \mathrm{~g} /$ ha efektifmenekan pertumbuhan gulma total hingga 12 MSA.

\section{Bobot Kering Gulma Daun Lebar}

Herbisida metil metsulfuron dosis $15-30 \mathrm{~g}$ /ha dan penyiangan mekanis efektifmengendalikan gulma golongan daun lebar pada 4-12 MSA. Herbisida metil metsulfuron dosis $30 \mathrm{~g} /$ ha memiliki daya kendali lebih tinggi dibandingkan dengan dosis $15 \mathrm{~g} /$ ha pada 12 MSA, dapat dilihat perlakuan dosis tertinggi memiliki daya kendali lebih tinggi terhadap gulma daun lebar dibandingkan perlakuan dosis terendah pada $12 \mathrm{MSA}$ (Tabel 2). Hal ini sejalan dengan hasil penelitian Khasanah dkk. (2015), aplikasi herbisida metil metsulfuron pada dosis $15-50 \mathrm{~g} /$ ha efektif menekan pertumbuhan gulmagolongan daun lebarhingga 12 MSA.

\section{Bobot Kering Gulma Rumput}

Berdasarkan penelitian yang telah dilakukan (Tabel3), herbisida metil metsulfuron dosis $15-30 \mathrm{~g} /$ ha dan penyiangan mekanis mengendalikan gulma rumput pada $4 \mathrm{MSA}$. Herbisida metil metsulfuron dosis $15 \mathrm{~g}$ /ha tidak mengendalikan gulma rumput sedangkan dosis 20 - $30 \mathrm{~g} /$ ha mengendalikan gulma rumput pada 8 MSA. Herbisida metil metsulfuron dosis $15-30 \mathrm{~g} /$ ha tidak mampu mengendalikan gulma rumput pada 12 MSA. Menurut Sembodo (2010), seletiktivitas dapat dipengaruhi oleh faktor tumbuhan yang berhubungan dengan herbisida yaitu selektivitas fisik, 
adanya lapisan tertentu atau zat penghalang pada tumbuhan yang mampu menahan sehingga herbisida tidak dapat mencapai bagian tumbuhan yang peka.

\section{Bobot Kering Gulma Teki}

Tabel 4 merupakan tabel bobot kering gulma teki akibat aplikasi herbisida metil metsulfuron. Herbisida metil metsulfuron taraf dosis $15 \mathrm{~g} /$ ha tidak mengendalikan gulma teki sedangkan dosis $20-30 \mathrm{~g} /$ ha dan penyiangan mekanis mengendalikan gulma golongan teki pada 4MSA. Herbisida metil metsulfuron dosis 15 - $30 \mathrm{~g} / \mathrm{ha}$ dan penyiangan mekanis mampu mengendalikan gulma golongan teki pada 8 MSA. Herbisida metil metsulfuron dosis $15-30 \mathrm{~g} / \mathrm{ha}$ dan penyiangan mekanis tidak mampu mengendalikan gulma golongan teki pada 12 MSA. Menurut Marcedo (1977) dalam Pamungkas dkk. (2017), sistem akar rimpang dan umbi yang kompleks pada gulma teki menyebabkan gulma golongan teki lebih tahan terhadap herbisida.

\section{Bobot Kering Gulma Borreria alata}

Borreria alata merupakan salah satu gulma dominan pada petak percobaan. Tabel 5 menunjukkan herbisida metil metsulfuron dosis $15-30 \mathrm{~g} / \mathrm{ha}$ dan penyiangan mekanis efektif mengendalikan gulma Borerria alata pada 4 - 12 MSA. Herbisida metil metsulfuron dosis $15-30 \mathrm{~g} /$ ha tidak menunjukan perbedaan daya kendali terhadap gulma Borreria alata pada 4-8 MSA. Herbisida metil metsulfuron dosis $25 \mathrm{~g} /$ ha dan $30 \mathrm{~g} / \mathrm{ha} \mathrm{memiliki} \mathrm{daya} \mathrm{kendali} \mathrm{lebih} \mathrm{tinggi}$

Tabel 3. Pengaruh perlakuan herbisida metil metsulfuron terhadap bobot kering gulma rumput

\begin{tabular}{|c|c|c|c|c|c|c|}
\hline \multirow{2}{*}{ Perlakuan } & \multicolumn{2}{|c|}{4 MSA } & \multicolumn{2}{|c|}{8 MSA } & \multicolumn{2}{|c|}{12 MSA } \\
\hline & Data asli & $\sqrt{\sqrt{ }(x+0,5)}$ & Data asli & $\sqrt{\sqrt{ }(x+0,5)}$ & Data asli & $\sqrt{ } \sqrt{(x+0,5)}$ \\
\hline & & & $\ldots \ldots . .(\mathrm{g} / 0$ & $\left.\mathrm{m}^{2}\right) \ldots \ldots \ldots$ & & \\
\hline Metil metsulfuron $15 \mathrm{~g} / \mathrm{ha}$ & 0,09 & $0,87 \mathrm{~b}$ & 2,40 & $1,34 \mathrm{ab}$ & 3,37 & $1,38 \mathrm{bc}$ \\
\hline Metil metsulfuron $20 \mathrm{~g} / \mathrm{ha}$ & 1,27 & $1,12 \mathrm{ab}$ & 0,78 & $1,15 \mathrm{~b}$ & 12,81 & $1,86 \mathrm{a}$ \\
\hline Metil metsulfuron $25 \mathrm{~g} / \mathrm{ha}$ & 0,45 & $0,97 \mathrm{~b}$ & 1,83 & $1,18 \mathrm{~b}$ & 3,79 & $1,37 \mathrm{bc}$ \\
\hline Metil metsulfuron $30 \mathrm{~g} / \mathrm{ha}$ & 0,47 & $0,94 \mathrm{~b}$ & 1,39 & $1,11 \mathrm{~b}$ & 5,44 & $1,53 \mathrm{~b}$ \\
\hline Penyiangan mekanis & 0,16 & $0,89 \mathrm{~b}$ & 0,68 & $1,12 \mathrm{~b}$ & 3,41 & $1,31 \mathrm{bc}$ \\
\hline Kontrol & 5,05 & $1,41 \mathrm{a}$ & 3,68 & $1,57 \mathrm{a}$ & 2,54 & $1,20 \mathrm{c}$ \\
\hline BNT 5\% & & 0,30 & & 0,24 & & 0,32 \\
\hline
\end{tabular}

Keterangan : Nilai tengah pada setiap kolom yang diikuti huruf yang sama tidak berbeda nyata menurut uji BNT pada taraf 5\%.

Tabel 4. Pengaruh perlakuan herbisida metil metsulfuron terhadap bobot kering gulma teki

\begin{tabular}{|c|c|c|c|c|c|c|}
\hline \multirow{2}{*}{ Perlakuan } & \multicolumn{2}{|c|}{$4 \mathrm{MSA}$} & \multicolumn{2}{|c|}{8 MSA } & \multicolumn{2}{|c|}{12 MSA } \\
\hline & Data asli & $\sqrt{ } \sqrt{(x+0,5)}$ & Data asli & $\sqrt{\sqrt{ }(x+0,5)}$ & Data asli & $\sqrt{\sqrt{ }(x+0,5)}$ \\
\hline & \multicolumn{6}{|c|}{ 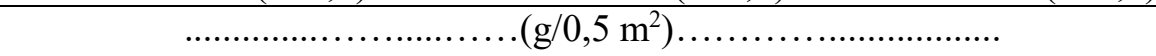 } \\
\hline Metil metsulfuron $15 \mathrm{~g} / \mathrm{ha}$ & 0,58 & $0,98 \mathrm{ab}$ & 0,39 & $0,94 \mathrm{~b}$ & 0,26 & $0,92 \mathrm{a}$ \\
\hline Metil metsulfuron $20 \mathrm{~g} / \mathrm{ha}$ & 0,00 & $0,84 \mathrm{c}$ & 0,66 & $1,00 \mathrm{~b}$ & 0,11 & $0,88 \mathrm{a}$ \\
\hline Metil metsulfuron $25 \mathrm{~g} / \mathrm{ha}$ & 0,00 & $0,84 \mathrm{c}$ & 0,00 & $0,84 \mathrm{~b}$ & 0,61 & $1,00 \mathrm{a}$ \\
\hline Metil metsulfuron $30 \mathrm{~g} / \mathrm{ha}$ & 0,00 & $0,88 \mathrm{bc}$ & 0,00 & $0,84 \mathrm{~b}$ & 0,18 & $0,88 \mathrm{a}$ \\
\hline Penyiangan mekanis & 0,15 & $0,84 \mathrm{c}$ & 0,55 & $0,98 \mathrm{~b}$ & 0,63 & $0,98 \mathrm{a}$ \\
\hline Kontrol & 1,15 & $1,09 \mathrm{a}$ & 0,58 & $1,26 \mathrm{a}$ & 0,54 & $0,97 \mathrm{a}$ \\
\hline BNT 5\% & & 0,14 & & 0,23 & & 0,14 \\
\hline
\end{tabular}

Keterangan : Nilai tengah pada setiap kolom yang diikuti huruf yang sama tidak berbeda nyata menurut uji BNT pada taraf 5\%. 
terhadap gulma Borreria alata dibandingkan dengan dosis $15 \mathrm{~g} /$ ha dan $20 \mathrm{~g} /$ ha pada 12 MSA. Perlakuan herbisida metil metsulfuron dosis $25 \mathrm{~g} /$ ha dan $30 \mathrm{~g} / \mathrm{ha}$ memiliki daya kendali lebih tinggi terhadap gulma Borreria alata dibandingkan perlakuan dosis terendah pada 12 MSA. Hasil pengamatan ini sejalan dengan penelitian Saputra (2018), bahwa herbisida metil metsulfuron dosis 20-46 g/ha mampu mengendalikan gulma Borreria alata pada 4-12 MSA.

\section{Bobot Kering Gulma Croton hirtus}

Tabel 6 merupakan tabel bobot kering gulma Croton hirtus akibat aplikasi herbisida metil metsulfuron. Herbisida metil metsulfuron dosis $15-$ 30 g/ha dan penyiangan mekanis mengendalikan gulma
Croton hirtus pada 4 MSAdan antardosis herbisida metil metsulfuron yang diuji tidak menunjukkan perbedaan daya kendali. Herbisida metil metsulfuron dosis 15 - $30 \mathrm{~g} / \mathrm{ha}$ dan penyiangan mekanis tidak mampu mengendalikan gulma Croton hirtus pada 8 MSA. Herbisida metil metsulfuron dosis $15 \mathrm{~g} / \mathrm{ha}, 25 \mathrm{~g} / \mathrm{ha}$ tidak mengendalikan gulma Croton hirtus, sedangakan dosis 20 dan $30 \mathrm{~g} /$ ha serta penyiangan mekanis mengendalikan gulma Croton hirtus pada 12 MSA.

\section{Bobot Kering Gulma Praxelis clematidea}

Hasil penelitian (Tabel 7) menunjukkan herbisida metil metsulfuron dosis $15-30 \mathrm{~g} /$ ha efektif mengendalikan gulma Praxelis clematidea serta tidak menunjukkan perbedaan daya kendali pada $4-12$

Tabel 5. Pengaruh perlakuan herbisida metil metsulfuron terhadap bobot kering gulma Borreria alata

\begin{tabular}{|c|c|c|c|c|c|c|}
\hline \multirow[b]{2}{*}{ Perlakuan } & \multicolumn{2}{|c|}{4 MSA } & \multicolumn{2}{|c|}{$8 \mathrm{MSA}$} & \multicolumn{2}{|c|}{$12 \mathrm{MSA}$} \\
\hline & Data Asli & $\sqrt{ } \sqrt{ }(x+0,5)$ & Data Asli & $\sqrt{ }(x+0,5)$ & Data Asli & $\sqrt{ }(x+0,5)$ \\
\hline & & 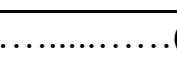 &, $\left.5 \mathrm{~m}^{2}\right) \ldots$ & & & \\
\hline Metil metsulfuron $15 \mathrm{~g} / \mathrm{ha}$ & 2,39 & $1,24 \mathrm{~b}$ & 0,46 & $0,91 \mathrm{~b}$ & 7,48 & $2,79 \mathrm{~b}$ \\
\hline Metil metsulfuron $20 \mathrm{~g} / \mathrm{ha}$ & 0,82 & $1,03 \mathrm{bc}$ & 0,02 & $0,72 \mathrm{~b}$ & 3,88 & $2,01 \mathrm{c}$ \\
\hline Metil metsulfuron $25 \mathrm{~g} / \mathrm{ha}$ & 0,93 & $0,98 \mathrm{bc}$ & 0,05 & $0,74 \mathrm{~b}$ & 0,41 & $0,92 \mathrm{~d}$ \\
\hline Metil metsulfuron $30 \mathrm{~g} / \mathrm{ha}$ & 0,08 & $0,87 \mathrm{c}$ & 0,38 & $0,91 \mathrm{~b}$ & 0,64 & $1,04 \mathrm{~d}$ \\
\hline Penyiangan mekanis & 0,44 & $0,94 \mathrm{bc}$ & 0,39 & $0,94 \mathrm{~b}$ & 2,62 & $1,75 \mathrm{c}$ \\
\hline Kontrol & 28,16 & $2,30 \mathrm{a}$ & 26,20 & $5,15 \mathrm{a}$ & 24,32 & $4,97 \mathrm{a}$ \\
\hline BNT 5\% & & 0,30 & & 0,34 & & 0,60 \\
\hline
\end{tabular}

Keterangan : Nilai tengah pada setiap kolom yang diikuti huruf yang sama tidak berbeda nyata menurut uji BNT pada taraf $5 \%$.

Tabel 6. Pengaruh perlakuan herbisida metil metsulfuron terhadap bobotkering gulma Croton hirtus

\begin{tabular}{|c|c|c|c|c|c|c|}
\hline \multirow{2}{*}{ Perlakuan } & \multicolumn{2}{|c|}{$4 \mathrm{MSA}$} & \multicolumn{2}{|c|}{$8 \mathrm{MSA}$} & \multicolumn{2}{|c|}{$12 \mathrm{MSA}$} \\
\hline & Data asli & $\sqrt{\sqrt{(x+0,5)}}$ & Data asli & $\sqrt{(x+0,5)}$ & Data asli & $\sqrt{(x+0,5)}$ \\
\hline & & & $\ldots \ldots \ldots \ldots$ (g &, $\left.5 \mathrm{~m}^{2}\right) \ldots$ & & \\
\hline Metil metsulfuron $15 \mathrm{~g} / \mathrm{ha}$ & 0,12 & $0,88 \mathrm{~b}$ & 0,08 & $0,76 \mathrm{a}$ & 0,30 & $0,88 \mathrm{ab}$ \\
\hline Metil metsulfuron $20 \mathrm{~g} / \mathrm{ha}$ & 1,53 & $1,13 \mathrm{~b}$ & 0,00 & $0,70 \mathrm{a}$ & 0,00 & $0,70 \mathrm{~b}$ \\
\hline Metil metsulfuron $25 \mathrm{~g} / \mathrm{ha}$ & 0,74 & $0,98 \mathrm{~b}$ & 0,07 & $0,75 \mathrm{a}$ & 0,37 & $0,88 \mathrm{ab}$ \\
\hline Metil metsulfuron $30 \mathrm{~g} / \mathrm{ha}$ & 0,91 & $1,03 \mathrm{~b}$ & 0,00 & $0,70 \mathrm{a}$ & 0,11 & $0,77 \mathrm{~b}$ \\
\hline Penyiangan mekanis & 0,28 & $0,91 \mathrm{~b}$ & 0,00 & $0,70 \mathrm{a}$ & 0,02 & $0,72 \mathrm{~b}$ \\
\hline Kontrol & 7,57 & $1,64 \mathrm{a}$ & 0,15 & $0,80 \mathrm{a}$ & 0,56 & $1,02 \mathrm{a}$ \\
\hline BNT 5\% & & 0,30 & & 0,09 & & 0,24 \\
\hline
\end{tabular}

Keterangan : Nilai tengah pada setiap kolom yang diikuti huruf yang sama tidak berbeda nyata menurut uji BNT pada taraf $5 \%$. 
Tabel 7. Pengaruh perlakuan herbisida metil metsulfuron terhadap bobotkering gulma Praxelis clematidea

\begin{tabular}{|c|c|c|c|c|c|}
\hline \multirow{2}{*}{ Perlakuan } & \multirow{2}{*}{$\begin{array}{c}\text { 4 MSA } \\
\text { Data asli }\end{array}$} & \multicolumn{2}{|c|}{8 MSA } & \multicolumn{2}{|c|}{$12 \mathrm{MSA}$} \\
\hline & & Data asli & $\sqrt{ }(x+0,5)$ & Data asli & $\sqrt{ } \sqrt{ }(x+0,5)$ \\
\hline & & & $\left(\mathrm{g} / 0,5 \mathrm{~m}^{2}\right)$ & & \\
\hline Metil metsulfuron $15 \mathrm{~g} / \mathrm{ha}$ & $0,00 \mathrm{~b}$ & 0,10 & $0,77 \mathrm{bc}$ & 7,50 & $0,84 \mathrm{c}$ \\
\hline Metil metsulfuron $20 \mathrm{~g} / \mathrm{ha}$ & $0,00 \mathrm{~b}$ & 0,01 & $0,71 \mathrm{c}$ & 0,00 & $0,84 \mathrm{c}$ \\
\hline Metil metsulfuron $25 \mathrm{~g} / \mathrm{ha}$ & $0,00 \mathrm{~b}$ & 0,00 & $0,70 \mathrm{c}$ & 0,12 & $0,87 \mathrm{c}$ \\
\hline Metil metsulfuron $30 \mathrm{~g} / \mathrm{ha}$ & $0,00 \mathrm{~b}$ & 0,00 & $0,70 \mathrm{c}$ & 0,00 & $0,84 \mathrm{c}$ \\
\hline Penyiangan mekanis & $0,25 \mathrm{~b}$ & 0,57 & $0,99 \mathrm{ab}$ & 2,57 & $1,23 \mathrm{~b}$ \\
\hline Kontrol & $10,45 \mathrm{a}$ & 0,78 & $1,10 \mathrm{a}$ & 6,58 & $1,62 \mathrm{a}$ \\
\hline BNT 5\% & 0,31 & & 0,25 & & 0,21 \\
\hline
\end{tabular}

Keterangan : Nilai tengah pada setiap kolom yang diikuti huruf yang sama tidak berbeda nyata menurut uji BNT pada taraf 5\%.

Tabel 8. Pengaruh perlakuan herbisida metil metsulfuron terhadap bobot kering gulma Ottochloa nodosa

\begin{tabular}{|c|c|c|c|c|c|c|}
\hline \multirow{2}{*}{ Perlakuan } & \multicolumn{2}{|c|}{$4 \mathrm{MSA}$} & \multicolumn{2}{|c|}{$8 \mathrm{MSA}$} & \multicolumn{2}{|c|}{12 MSA } \\
\hline & Data asli & $\sqrt{\sqrt{ }(x+0,5)}$ & Data asli & $\sqrt{\sqrt{ }(x+0,5)}$ & Data asli & $\sqrt{\sqrt{ }(x+0,5)}$ \\
\hline & & & $\ldots \ldots \ldots(\mathrm{g} / 0$ & $\left.\mathrm{m}^{2}\right) \ldots \ldots \ldots$ & & \\
\hline Metil metsulfuron $15 \mathrm{~g} / \mathrm{ha}$ & 0,07 & $0,86 \mathrm{~b}$ & 0,33 & $0,92 \mathrm{a}$ & 1,03 & $1,04 \mathrm{~b}$ \\
\hline Metil metsulfuron $20 \mathrm{~g} / \mathrm{ha}$ & 0,40 & $0,94 \mathrm{~b}$ & 0,00 & $0,84 \mathrm{a}$ & 11,02 & $1,80 \mathrm{a}$ \\
\hline Metil metsulfuron $25 \mathrm{~g} / \mathrm{ha}$ & 0,03 & $0,85 \mathrm{~b}$ & 0,00 & $0,84 \mathrm{a}$ & 1,63 & $1,10 \mathrm{~b}$ \\
\hline Metil metsulfuron $30 \mathrm{~g} / \mathrm{ha}$ & 0,00 & $0,84 \mathrm{~b}$ & 0,33 & $0,92 \mathrm{a}$ & 2,89 & $1,29 \mathrm{~b}$ \\
\hline Penyiangan mekanis & 0,03 & $0,85 \mathrm{~b}$ & 0,00 & $0,84 \mathrm{a}$ & 1,51 & $1,08 \mathrm{~b}$ \\
\hline Kontrol & 2,12 & $1,21 \mathrm{a}$ & 0,76 & $1,00 \mathrm{a}$ & 1,65 & $1,12 \mathrm{~b}$ \\
\hline BNT $5 \%$ & & 0,18 & & 0,20 & & 0,43 \\
\hline
\end{tabular}

Keterangan : Nilai tengah pada setiap kolom yang diikuti huruf yang sama tidak berbeda nyata menurut uji BNT pada taraf $5 \%$.

MSA. Hal ini sesuai dengan hasil penelitian Saputra (2018), herbisida metil metsulfuron dosis $20-46,6 \mathrm{~g} /$ ha mampu mengendalikan gulma daun lebar termasuk gulma Praxelis climatidea hingga 12 MSA.

\section{Bobot Kering Ottochloa nodosa}

Ottochloa nodosa merupakan salah satu gulma dominan pada petak percobaan. Tabel 8 menunjukkan herbisida metil metsulfuron dosis $15-30 \mathrm{~g} / \mathrm{ha}$ dan penyiangan mekanis mengendalikan gulma Ottochloa nodosa dengan perlakuan antardosis yang diuji tidak menunjukkan perbedaan daya kendali pada pengamatan 4 MSA. Herbisida metil metsulfuron dosis 15 - $30 \mathrm{~g} / \mathrm{ha}$ dan penyiangan mekanis tidak mengendalikan gulma Ottochloa nodosa pada 8-12 MSA. Menurut Sembodo (2010), gulma Ottochloa nodosa memiliki biji dalam jumlah banyak dan dapat berkembang biak menggunakan stolon. Menurut Suryani (1991) dalam Nainggolan (2014), aplikasi herbisida tidak seluruhnya mematikan bagian stolon gulma Ottochloa nodosa sehingga stolon ini tetap hidup kemudian berkembang biak.

Hal ini diduga menyebabkan aplikasi herbisida metil metsulfuron hanya mampu menekan pertumbuhan sementara, namun tidak mematikan gulma Ottochloa nodosa secara total.

Selain itu, herbisida metil metsulfuron bersifat sistemik dan selektif terhadap gulma daun lebar (Djojosumarto, 2008). Menurut Sembodo (2010) herbisida yang masuk ke dalam sel, dapat ditranslokasikan ke sel-sel lainnya dan sebagian ada yang tidak 
mobil. Sifat mobilitas herbisida dalam sel memiliki kontribusi terhadap selektivitas herbisida. Diduga herbisida yang masuk ke dalam tubuh gulma sebagian ada yang tidak mobil sehingga herbisida tidak sampai ke site of action dan menyebabkan gulma Ottochloa nodosa tidak dapat dikendalikan pada 8-12 MSA.

\section{Bobot Kering Gulma Axonopus compressus}

Herbisida metil metsulfuron dosis $15-30 \mathrm{~g} / \mathrm{ha}$ dan penyiangan mekanis mengendalikan gulma Axonopus compressus pada 4 MSA dengan daya kendali antardosis herbisida metil metsulfuron yang diuji tidak menunjukkan perbedaan. Herbisida metil metsulfuron dosis $15-30 \mathrm{~g} /$ ha dan penyiangan mekanis tidak mengendalikan guilma Axonopus compressus pada 8-12 MSA (Tabel 9). Menurut Suryani (1991) dalam Nainggolan (2014), permukaan daun gulma yang halus, berlilin, dan berambut lebat lebih sulit dalam penetrasi herbisida yang diaplikasikan bila dibandingkan dengan permukaan yang tidak berlilin atau berambut. Menurut Haryanto (2016), gulma Axonopus compressus memiliki bentuk daun lanset, bertulang daun sejajar dengan permukaan daun bergelombang serta memiliki rambut yang meyebar pada bagian atas permukaan daun. Hal ini diduga menyebabkan herbisida metil metsulfuron dosis $15-30 \mathrm{~g} /$ ha yang diserap oleh gulma Axonopus compressus lebih sedikit sehingga kurang efektifmengendalikan gulma Axonopus compressus pada 8 dan 12 MSA.

\section{Koefisien Komunitas dan perubahan komposisi}

Berdasarkan hasil pengamatan 4, 8, dan 12 MSA, diketahui terjadi perubahan komposisi antara 2 komunitas gulma yang dibandingkan. Perlakuan herbisida metil metsulfuron dosis $15-30 \mathrm{~g} / \mathrm{ha}$ dan penyiangan mekanis menyebabkan perubahan komposisi gulma pada 4-12 MSA, hal ini ditandai dengan nilai koefisien komunitas antara perlakuan yang dibandingkan petak kontrol<75\% (Tabel 10).

Berdasarkan penelitian yang telah dilakukan, herbisida metil metsulfuron dosis $30 \mathrm{~g} /$ ha dibandingkan dengan petak kontrol memiliki kesamaan komposisi gulma terendah yaitu $48 \%$. Jenis gulma yang mendominasi pada 4 MSA petak perlakuan herbisida metil metsulfuron dosis $30 \mathrm{~g} / \mathrm{ha}$ adalah Croton hirtus, sedangkan pada petak kontrol didominasi oleh Borreria alata. Aplikasi herbisida metil metsulfuron dosis $15-30 \mathrm{~g} / \mathrm{ha}$ menyebabkan terjadinya perubahan komposisi jenis gulma dari Borreria alata menjadi Croton hirtus.

Tabe1 9. Pengaruh perlakuan herbisida metil metsulfuron terhadap bobot kering gulma Axonopus compressus

\begin{tabular}{|c|c|c|c|c|c|c|}
\hline \multirow{2}{*}{ Perlakuan } & \multicolumn{2}{|c|}{$4 \mathrm{MSA}$} & \multicolumn{2}{|c|}{$8 \mathrm{MSA}$} & \multicolumn{2}{|c|}{$12 \mathrm{MSA}$} \\
\hline & Data asli & $\sqrt{ } \sqrt{(x+0,5)}$ & Data asli & $\sqrt{ } \sqrt{(x+0,5)}$ & Data asli & $\sqrt{ } \sqrt{ }(x+0,5)$ \\
\hline & \multicolumn{6}{|c|}{ 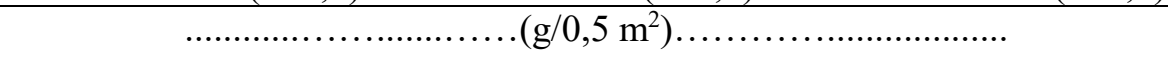 } \\
\hline Metil metsulfuron $15 \mathrm{~g} / \mathrm{ha}$ & 0,00 & $0,84 \mathrm{~b}$ & 1,11 & $1,08 \mathrm{a}$ & 1,50 & $1,16 \mathrm{a}$ \\
\hline Metil metsulfuron $20 \mathrm{~g} / \mathrm{ha}$ & 0,11 & $0,87 \mathrm{~b}$ & 0,26 & $0,91 \mathrm{a}$ & 0,34 & $0,92 \mathrm{bc}$ \\
\hline Metil metsulfuron $25 \mathrm{~g} / \mathrm{ha}$ & 0,00 & $0,84 \mathrm{~b}$ & 0,86 & $1,02 \mathrm{a}$ & 0,80 & $1,04 \mathrm{abc}$ \\
\hline Metil metsulfuron $30 \mathrm{~g} / \mathrm{ha}$ & 0,00 & $0,84 \mathrm{~b}$ & 0,42 & $0,97 \mathrm{a}$ & 1,15 & $1,10 \mathrm{ab}$ \\
\hline Penyiangan mekanis & 0,07 & $0,86 \mathrm{~b}$ & 0,26 & $0,91 \mathrm{a}$ & 0,45 & $0,97 \mathrm{abc}$ \\
\hline Kontrol & 2,19 & $1,14 \mathrm{a}$ & 0,56 & $0,99 \mathrm{a}$ & 0,06 & $0,86 \mathrm{c}$ \\
\hline BNT 5\% & & 0,24 & & 0,23 & & 0,21 \\
\hline
\end{tabular}

Keterangan : Nilai tengah pada setiap kolom yang diikuti huruf yang sama tidak berbeda nyata menurut uji BNT pada taraf $5 \%$. 
Tabel 10. Perubahan komposisi jenis gulma pada 4-12 MSA(\%)

\begin{tabular}{lccc}
\hline \multirow{2}{*}{ Perbandingan } & \multicolumn{3}{c}{ Nilai Koefisien komunitas (\%) } \\
\cline { 2 - 4 } & 4 MSA & 8 MSA & 12 MSA \\
\hline Metil metsulfuron 15 g/ha vs Kontrol & 57 & 45 & 66 \\
Metil metsulfuron 20 g/ha vs Kontrol & 59 & 43 & 41 \\
Metil metsulfuron 25 g/ha vs Kontrol & 65 & 30 & 40 \\
Metil metsulfuron 30 g/ha vs Kontrol & 48 & 42 & 35 \\
Penyiangan mekanis vs Kontrol & 74 & 61 & 69 \\
\hline
\end{tabular}

Hasil pengamatan 8 MSA, herbisida metil metsulfuron dosis $25 \mathrm{~g}$ /ha dibandingkan dengan petak kontrol memiliki kesamaan komposisi gulma terendah yaitu $30 \%$. Jenis gulma yang mendominasi pada 8 MSA petak perlakuan herbisida metil metsulfuron dosis 25 g/ha adalah gulma Axonopus compressus, sedangkan pada petak kontrol didominasi oleh Borreria alata. Aplikasi herbisida metil metsulfuron dosis $15-30 \mathrm{~g} / \mathrm{ha}$ menyebabkan terjadinya perubahan komposisi jenis gulma dari Borreria alata menjadi Axonopus compressus.

Herbisida metil metsulfuron dosis $30 \mathrm{~g} / \mathrm{ha}$ dibandingkan dengan petak kontrol memiliki kesamaan komposisi gulma terendah yaitu 35\%. Jenis gulma yang mendominasi pada $12 \mathrm{MSA}$ petak perlakuan herbisida metil metsulfuron dosis $30 \mathrm{~g} / \mathrm{ha}$ adalah gulma Ottochloa nodosa, sedangkan pada petak kontrol didominasi oleh Borreria alata. Aplikasi herbisida metil metsulfuron dosis $15-30 \mathrm{~g} /$ ha menyebabkan terjadinya perubahan komposisi jenis gulma dari Borreria alata menjadi Ottochloa nodosa.

\section{Fitotoksisitas Tanaman Karet}

Hasil pengamatan tidak menunjukkan terjadinya gejala keracunan akibat aplikasi herbisida metil metsulfuron dosis 15 - $30 \mathrm{~g} / \mathrm{ha}$ dalam mengendalikan gulma pada baris tanaman karet. Tidak terjadinya keracunan tanaman karet ditunjukkan dengan membandingkan antara perlakuan dosis herbisida metil metsulfuron dengan penyiangan mekanis pada tanaman karet. Pada tanaman karet tidak terjadi perubahan bentuk dan atau warna daun serta pertumbuhan karet tetap normal. Daun tanaman karet terlihat berwarna hijau dan bentuknya normal, daun tidak terjadi penggulungan dan atau pengkritingan sehingga dapat disimpulkan tidak terdapat gejala keracunan pada tanaman karet akibat aplikasi herbsisida metil metsulfuron.

\section{KESIMPULAN}

Berdasarkan hasil penelitian yang telah dilakukan maka dapat disimpulkan herbisida metil metsulfuron dosis $15-30 \mathrm{~g} /$ ha efektif mengendalikan gulma total, gulma daun lebar, Borreria alata, dan Praxelis climatidea pada 4-12 MSA. Herbisida metil metsulfuron dosis $20-30 \mathrm{~g} /$ ha mengendalikan gulma rumput dan teki sampai $8 \mathrm{MSA}$. Herbisida metil metsulfuron dosis 15 - 30 g/ha mengendalikan gulma Axonopus compressus, Croton hirtus, dan Ottochloa nodosa pada 4 MSA di perkebunan karet TBM. Aplikasi herbisida metil metsulfuron dosis $15-30 \mathrm{~g} /$ ha menyebabkan terjadinya perubahan komposisi gulma Borreria alata menjadi Croton hirtus pada 4 MSA, Borreria alata menjadi Axonopus compressus 
pada 8 MSA, dan Borreria alata menjadi Ottochloa nodosa pada 12 MSA di perkebunan karet TBM. Aplikasi herbisida metil metsulfuron dosis 15-30 g/ ha tidak menyebabkan terjadinya keracunan terhadap tanaman karet TBM.

\section{DAFTAR PUSTAKA}

Direktorat Jenderal Perkebunan. 2018. Statistik Perkebunan Indonesia KomoditasKaret. http://ditjenbun.pertanian.go.id. Diakses pada 19 Desember 2019.

Djojosumarto, P. 2008. Pestisida dan Aplikasinya. PT Agromedia Pustaka. Tanggerang. $340 \mathrm{hlm}$.

Evizal, R. 2015. Karet: Manajemen dan Pengelolaan Kebun. Plantaxia. Yogyakarta. $154 \mathrm{hlm}$.

Haryanto, D. 2016. Identifikasi Gulma di Lahan Pertanian Padi (Oryza sativa L.) Pasang Surut di Desa Pagayut Kecamatan Pemulutan Kabupaten Ogan Ilir dan Sumbang Sihnya pada Pokok Bahasan Keanekaragaman Hayati Kelas X di MA/SMA. Skripsi. UIN Raden Fatah. Palembang. $50 \mathrm{hlm}$.

Hastuti, N. Y., D. R. J. Sembodo., dan R. Evizal. 2015. Efikasi HerbisidaAmonium Glufosinatt Gulma Umum pada Perkebunan Karet yang Menghasilkan (Hevea brasiliensis). Jurnal Penelitian Terapan. 15(1):41-47.

Khasanah, N. H., N. Sriyani., dan R. Evizal. 2015. Efikasi Herbisida Metil Metsulfuron pada Pertanaman Kelapa Sawit (Elaesis guinensis Jacq). Yang Belum Menghasilkan. Pertaninan Terapan. 15(1):1-7.
Koriyando, V., H. Susanto., dan Sugiatno. 2014. Efikasi Herbisida Metil Metsulfuron untuk Mengendalikan Gulma pada Tanaman Kelapa Sawit (Elaeis Guineensis Jacq.) Menghasilkan. Jurnal Agrotek Tropika. 2 (3): 375-381.

Nainggolan, B. B. 2014. Pengelolaan Gulma dengan Herbisida Kontak Paraquat Diklorida 283 g/1 pada Tanaman Kelapa Sawit (Elaeis guineensis Jacq.) Belum Menghasilkan (TBM) di Kebun Cisalak Baru PTPN VIII. Skripsi. IPB. Bogor. $76 \mathrm{hlm}$.

Pamungkas, H., D. R. J. Sembodo., dan R. Evizal. 2018. Efikasi Herbisida Isopropilamina Glifosat dalam Mengendalikan Gulma pada Perkebunan Karet (Havea brasiliensis) Belum Menghasilkan. Pertanian Terapan. 18(2):101-109.

Saputra, D. E. E. 2018. Efikasi Herbisida Metil Metsulfuron terhadap Gulma pada Lahan Kelapa Sawit (Elaeis guineensis Jacq) Tanaman Menghasilkan. Skripsi. Universitas Lampung. Bandar Lampung. $74 \mathrm{hlm}$.

Sembodo, D.R. J. 2010. Gulma dan Pengelolaannya. Graha Ilmu. Yogyakarta. $166 \mathrm{hlm}$.

Siregar, N. T. S. 2002. Aplikasi Kombinasi Herbisida Sulfosat $48 \%$ dan Metil Metsulfuron $20 \%$ pada Gawangan Tanaman Karet (Hevea brasiliensis). Skripsi. IPB. Bogor. $68 \mathrm{hlm}$.

Supawan, I. G. dan Haryadi. 2014. Efektivitas Herbisida IPA Glifosat 486 SL untuk Pengendalian Gulma pada Budidaya Tanaman Karet (Hevea brasiliensis Muell. Arg) Belum Menghasilkan. Bul.Agrohorti. 2(1):95-103. 
Susanto, H., R. Evizal, dan Sugiatno. 2020. Kajian Efikasi Herbisida Ametrin dan Kombinasi Ametrin + (2,4-D atau Metil Metsulfuron) terhadap Pertumbuhan Gulma pada Budidaya Tebu Lahan Kering. Jurnal Agrotropika. 19(1): 57-62.
Tjitrosoedirdjo, S., I. H. Utomo, dan J. Wiroatmodjo. 1984. Pengelolaan Gulma di Perkebunan. Gramedia. Jakarta. 207 hlm. 